\title{
SHEEP CELL AGGLUTINATION TEST IN CHRONIC INTERSTITIAL PULMONARY FIBROSIS
}

BY

\author{
RICHARD WARD AND RANDAL STALKER
}

Royal Infirmary, Blackburn, Lancs.

In the last few years we have seen nineteen cases which we have regarded as showing the typical features of chronic interstitial pulmonary fibrosis. More recently, stimulated by our interest in the intrathoracic manifestations of rheumatoid disease, we have carried out the sheep cell agglutination test (S.C.A.T.) at regular intervals as a routine measure. We have been interested to find that the test has been at some time positive in over half the patients studied.

\section{Material}

The group of patients consists of ten males and nine females. The average age is 57 years. We have excluded patients having clinical rheumatoid arthritis.

\section{Methods}

It is now reasonable to assume that the diagnosis of chronic interstitial pulmonary fibrosis can be made on finding the typical clinical, radiological, and respiratory physiological picture (Scadding, 1960; Livingstone, Lewis, Reid, and Jefferson, 1964). We have not therefore attempted to obtain lung biopsies, except in one somewhat unusual case, and we have post mortem histology in only another three cases. Routine investigations included examination of urine and sputum, blood counts, and tuberculin tests. Serum protein estimations, the S.C.A.T., and the latex-fixation test were done in all patients, except one in whom death occurred within hours of admission to hospital.

Respiratory function tests were done in six patients who had a positive S.C.A.T. These included analysis of the spirographic tracing, $\mathrm{PCO}_{2}$, oxygen saturation at rest, diffusion tests at rest and exercise, and estimation of the nitrogen-washout time. In most of the other cases estimations of vital capacity, F.E.V.I., and $\mathrm{PCO}_{2}$ were done in the clinic. All patients had postero-anterior chest films taken on several occasions and most of them have had $x$ rays of hands, feet, and cervical spine in addition. This was done in all cases with a positive S.C.A.T. in order to reveal any radiological evidence of rheumatoid arthritis not clinically manifest. Bronchograms were available in three cases.

\section{Results}

The results of the S.C.A.T. and latex-fixation tests in the nineteen cases observed are set out in a Table (overleaf), with the age, sex, total duration of symptoms, and maximum serum globulin estimation recorded. The present state and a few special features of each case are noted in the last column Three typical cases are described below in more detail.

\section{Case Reports}

Case 1, a male power-loom overlooker aged 53, gave a vague history of "rheumatism" in the feet in 1939, no recurrence. An M.M.R. chest $x$ ray passed as normal in 1955.

Examination.-When first seen in May, 1963, he complained of shortness of breath for 2 years, with cough morning and evening. Little mucoid sputum. Weight increasing. No joint symptoms.

Definite clubbing, slight cyanosis, fine râles over both lungs. Chest $x$ ray showed diffuse nodulation and reticulation in all zones (Fig. 1, opposite).

S.C.A.T. positive 1/90. Latex-fixation test negative. Albumin/globulin (A/G) ratio 1·4:1 0 (albumin 5 g./100 $\mathrm{ml}$; globulin $3.6 \mathrm{~g} . / 100 \mathrm{ml}$.). Haemoglobulin 110 per cent. Tuberculin test positive.

Progress.-He continued working, being seen at intervals at the Chest Clinic. On October 9, 1963, the S.C.A.T. was positive $1 / 270$, latex positive. Respiratory function tests showed hyperventilation at rest. Vital capacity $2 \cdot 2$ litres. Inspiratory capacity $1 \cdot 3$ litres. Expiratory capacity 0.9 litres. F.E.V. (one second) was 100 per cent of vital capacity. Oxygen saturation at rest 73 per cent., $\mathrm{PCO}_{2} 40 \mathrm{~mm}$. $\mathrm{Hg}$; diffusion $6.3 \mathrm{ml} . / \mathrm{min}$./ $\mathrm{mm}$. $\mathrm{Hg}$ at rest and $9.7 \mathrm{ml}$. on exercise. $\mathrm{N} 2$ wash-out time normal.

When he was seen again on February 26, 1964, the A/G ratio was $0.9: 1.0$ (albumin $3.9 \mathrm{~g} . / 100 \mathrm{ml}$; ; globulin $4.2 \mathrm{~g} . / 100 \mathrm{ml}$.). S.C.A.T. positive $1 / 90$, latex positive. $x$ rays of hands, feet, and neck on March 31, 1964, were normal apart from early osteo-arthritic changes in the first metatarso-phalangeal joints. 


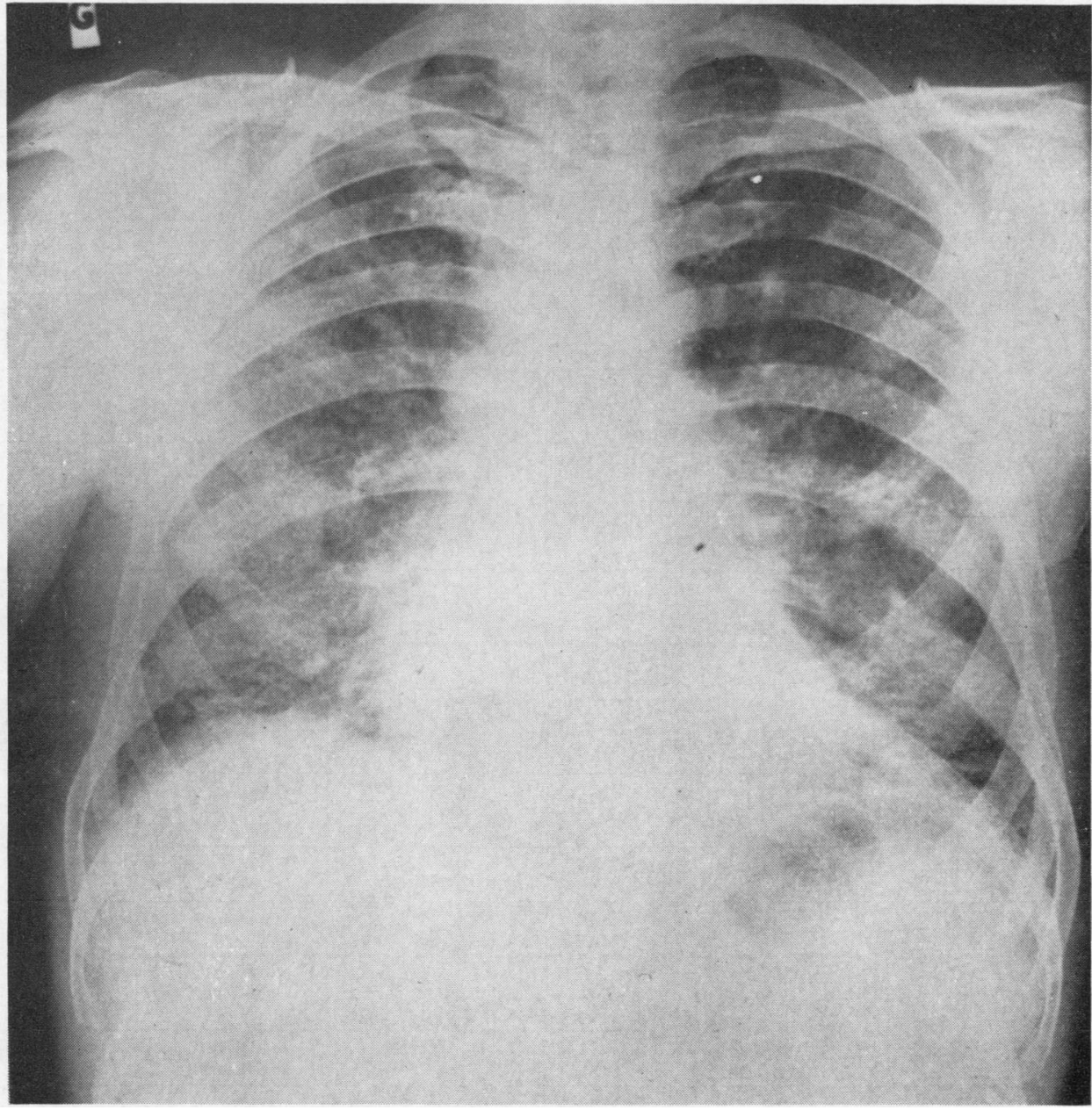

Fig. 1.-Chest $x$ ray of Case 1, showing diffuse bilateral granular nodulation and reticulation most confluent at the bases with blurring of the lower cardiac margins, typical of chronic interstitial pulmonary fibrosis.

Case 6, a housewife aged 58, gave a history of cough and scanty mucoid sputum, and increasing shortness of breath on exertion for 5 years. She was still working part-time as a home help; there were no joint symptoms, but her sister suffered from rheumatoid arthritis.

Examination.-She was referred to the Chest Clinic on November 14, 1963, after an M.M.R. $x$ ray which showed a kypho-scoliosis with faint bilateral reticulation throughout both lung fields and confluent reticulation at the right apex. She had clubbing of the finger nails and râles over both lungs. Varicose veins were present in both legs.

Sputum cultures were negative for tubercle bacilli. Haemoglobin 86 per cent. Erythrocyte sedimentation rate $27 \mathrm{~mm} . / 1 \mathrm{hr}$. S.C.A.T. and latex tests on November
14, 1963, negative. Vital capacity $1500 \mathrm{ml}$; Pco. 38 $\mathrm{mm}$. Hg. Tuberculin test positive. Serum globulin $3 \cdot 7$ g./100 ml. Electrophoresis showed excess gamma globulin.

Progress.-When seen again on February 11, 1964, her condition was unchanged, but the S.C.A.T. was positive $1 / 90$, and the latex test strongly positive.

On September 6, 1964, she was no more breathless and remained at work; the S.C.A.T. and latex tests had become negative.

She had no signs or symptoms of articular disease. $X$ rays of the neck were normal. $X$ rays of the feet showed early osteo-arthritic changes only, but in the hands tiny erosions on the ulnar sides of the heads of the second and third left metacarpal bones could be seen, 
RESULTS OF SHEEP CELL AGGLUTINATION AND LATEX TESTSS I.

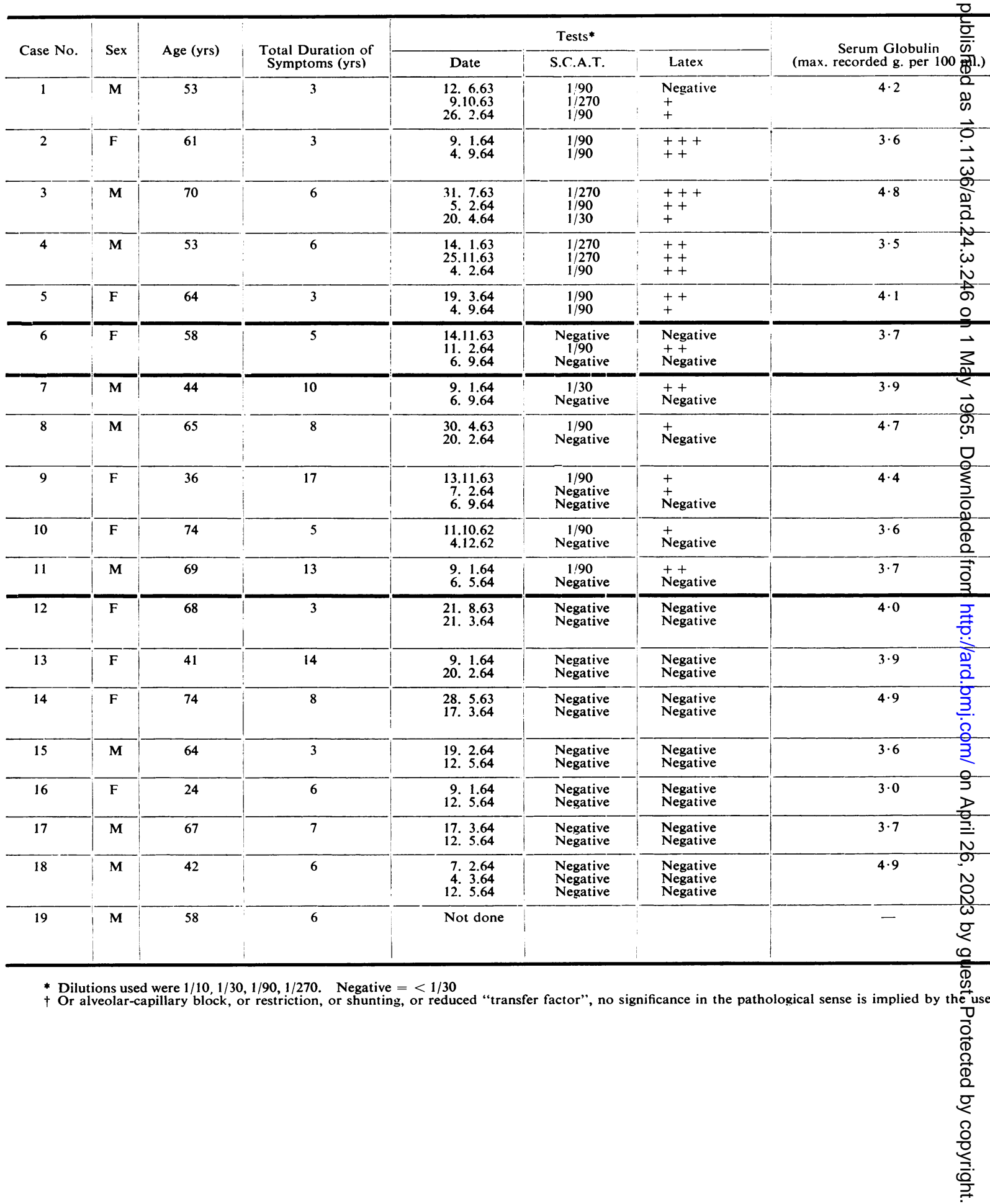


NINETEEN CASES OF CHRONIC INTERSTITIAL PULMONARY FIBROSIS

\section{Remarks}

Working
Lung function tests show "diffusion defect",, without airway obstruction (Fig. 1)

Does housework

Lung function tests show diffusion defect, without airway obstruction. Excess $\gamma$ globulin. Minute erosion head of metacarpal left index finger (Fig. 7)

Respiratory cripple

Lung function tests show diffusion defect, without airway obstruction. Excess $\gamma$ globulin. Steroids tried without benefit

Died

Histology showed interstitial pulmonary fibrosis with honeycombing. Steroids tried without benefit

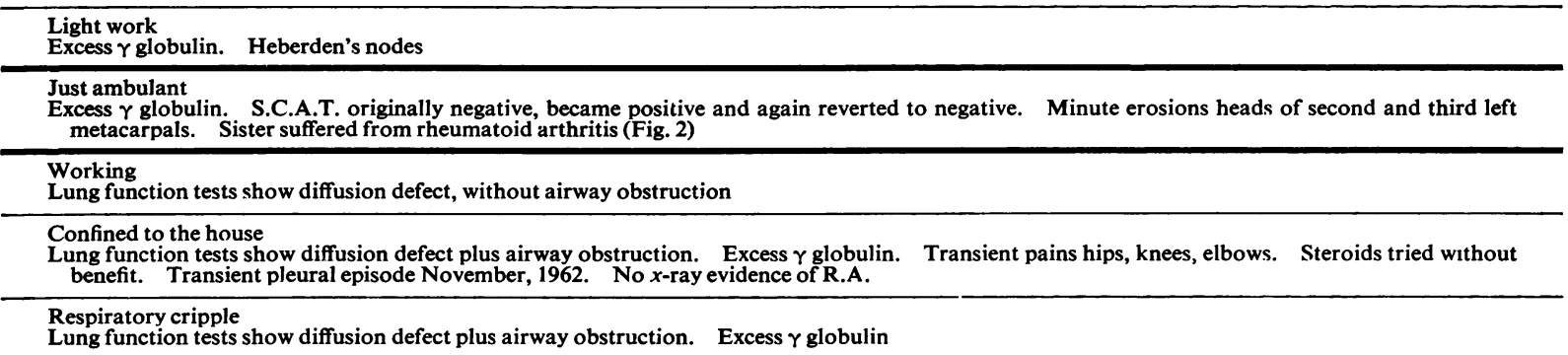

Died

Steroids tried without benefit. V.C. $750 \mathrm{cc} . \mathrm{PCO}_{2} 40 \mathrm{~mm} . \mathbf{H g}$.

Just ambulant

Irregularity of texture in head of metacarpal of right index finger. Slight demineralization

Died

Crepitus in knee joints. D.J.D. of hands plus ?? early R.A. (see Case history)

Lung section showed interstitial pulmonary fibrosis with honeycombing (Figs $3,4,5,6$ )

Respiratory cripple

Excess $\beta$ and $\gamma$ globulins. Steroids tried without benefit

Ambulant

Serial $x$ rays since 1960 show bilateral granular mottling and gradual appearance of cystic reticulation. Heberden's nodes, also? early erosion medial aspect of head of first left metatarsal (Fig. 8)

Working

Moderate dyspnoea; doing housework

Lung biopsy showed interstitial fibrosis. Aunt and grandmother suffered from rheumatoid arthritis

Ambulant

Ambulant

Serial chest $x$ rays since 1958 show granular mottling throughout. Reticulation originally confined to the apices gradually extended downwards obscuring the outlines of both heart borders

Followed for 3 years but lost sight of. Subsequently admitted to hospital and died the same day. Lung section showed extensive areas of welldeveloped fibrosis with honeycombing

of the expression "diffusion defect" (Finley, Swenson, and Comroe, 1962; West, 1964) 
although the joint spaces were well maintained and no demineralization appeared to be present (Fig. 2). The radiologist considered that early rheumatoid disease could not be excluded.

Case 12, a housewife aged 68, who had done some farm work, was first seen in March, 1962, with a history of shortness of breath since an attack of influenza one year before, troublesome cough, mucoid sputum, and loss of 2 stones in weight. She had had intermittently for 2 years slight aching in the shoulders and knees.

Examination.-Marked finger clubbing was present with Heberden's nodes, but no ulnar deviation, and no rheumatoid nodules. Cyanosis was present. Fine râles over both lung fields. B.P. 180/90. Varicose veins left leg and foot.

Chest $x$ ray showed granular mottling and small-sized reticulation throughout both lung fields with slight cardiac enlargement and irregularity of the heart borders (Figs 3 and 4, opposite). Haemoglobin 94 per cent., erythrocyte sedimentation rate $45 \mathrm{~mm}$./1 hour. S.C.A.T. and latex test on August 21, 1963, negative. Tuberculin test positive. Serum globulin $4 \mathrm{~g} . / 100 \mathrm{ml}$. L.E.-cells absent. Vital capacity 1 litre; $\mathbf{P C O}_{2} 40 \mathrm{~mm}$. $\mathbf{H g}$.

Progress.-Her condition remained unchanged till February, 1964, when she complained of increased breathlessness, pain across the front of the chest on exertion, and slight ankle swelling. An electrocardiogram on March 3,1964, revealed a left bundle branch block. On admission to hospital a loud third heart sound was present and a systolic murmur could be heard at the aortic area and also at the apex. Râles were present over both lungs and also harsh rhonchi. The B.P. was $125 / 80$. Crepitus was present in both knee joints. Cyanosis and breathlessness became more severe in spite of treatment and the sputum became more tenacious and purulent. The S.C.A.T. and latex tests were still negative.

$X$ rays of the hands on March 16, 1964, showed generalized demineralization and lipping of the interphalangeal joints. There was subluxation of the metacarpo-phalangeal joints of both thumbs, and forward subluxation of the first phalanges on the metacarpals of the thumbs and index fingers of both hands, but little ulnar deviation of the fingers. There were small erosions at the base of the styloid process of the left ulna (Fig. 5, opposite), but no erosions could be seen in the metacarpals. The radiologist considered the changes to be mainly due to osteo-arthritis but could not absolutely exclude the presence of rheumatoid disease.

The patient died on April 6, 1964 . A post mortem examination showed interstitial pulmonary fibrosis with bilateral honeycombing (Fig. $6 a-c$, overleaf), and right ventricular hypertrophy.

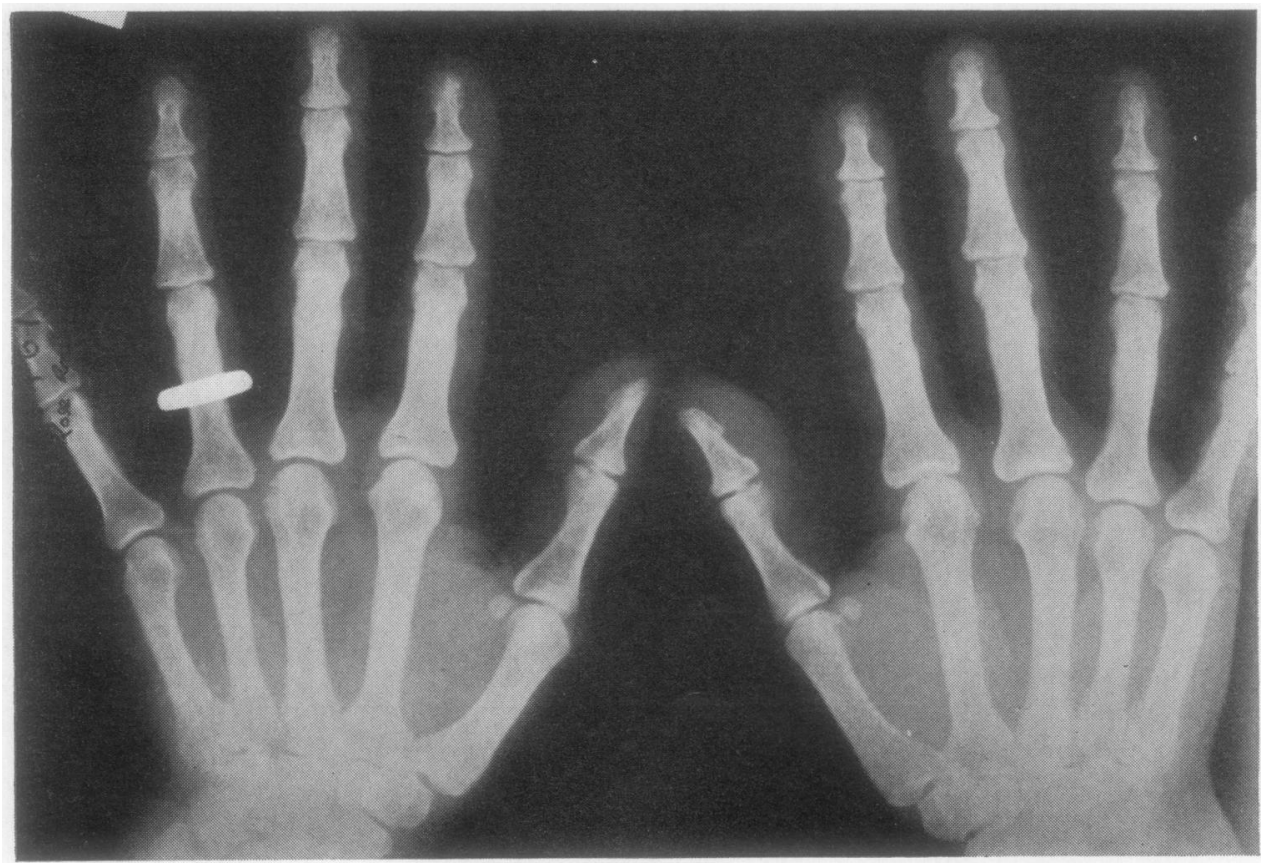

Fig. 2.- $X$ ray of left hand of Case 6, showing tiny erosions on ulnar aspects of heads of metacarpals of left middle and index fingers. 


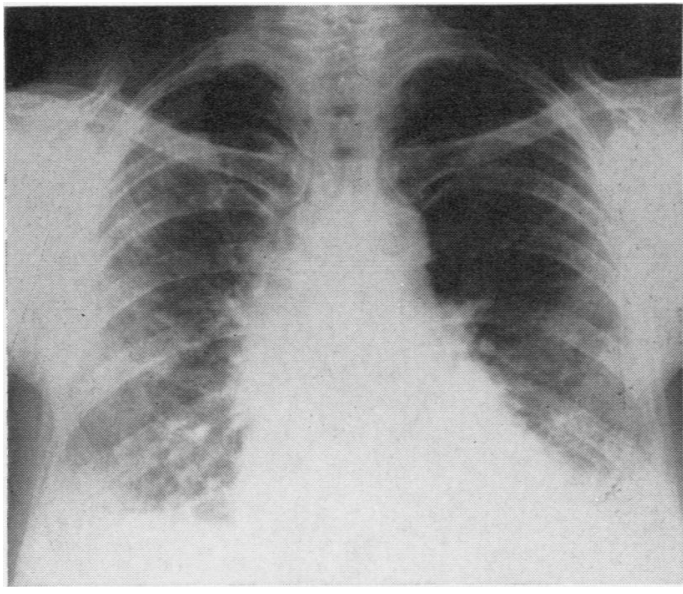

Fig. 3. - Chest $x$ ray of Case 12 (16.5.62), showing more reticulation and less granulation than Case 1.

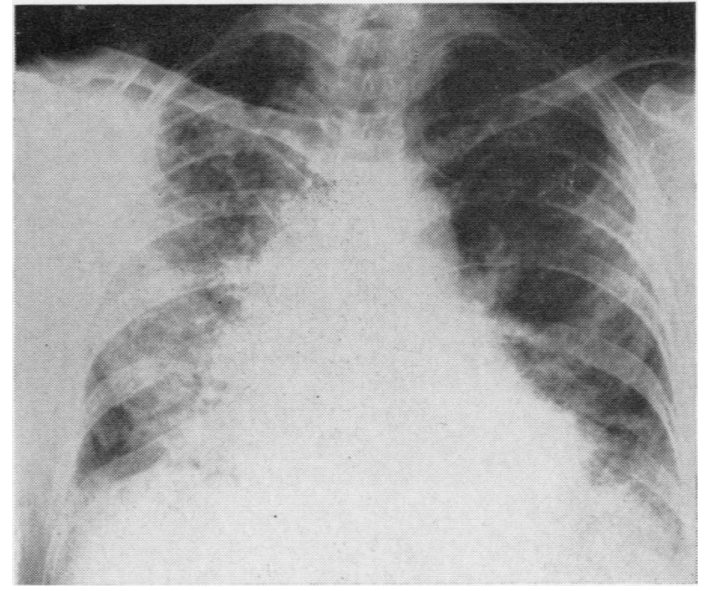

Fig. 4.-Case 12, 2 years later (9.3.64).

Fig. 5. - Case 12, showing osteo-arthritic changes but also rheumatoid disease as evidenced by small erosions in the styloid process of the head of the left ulna. S.C.A.T. negative.
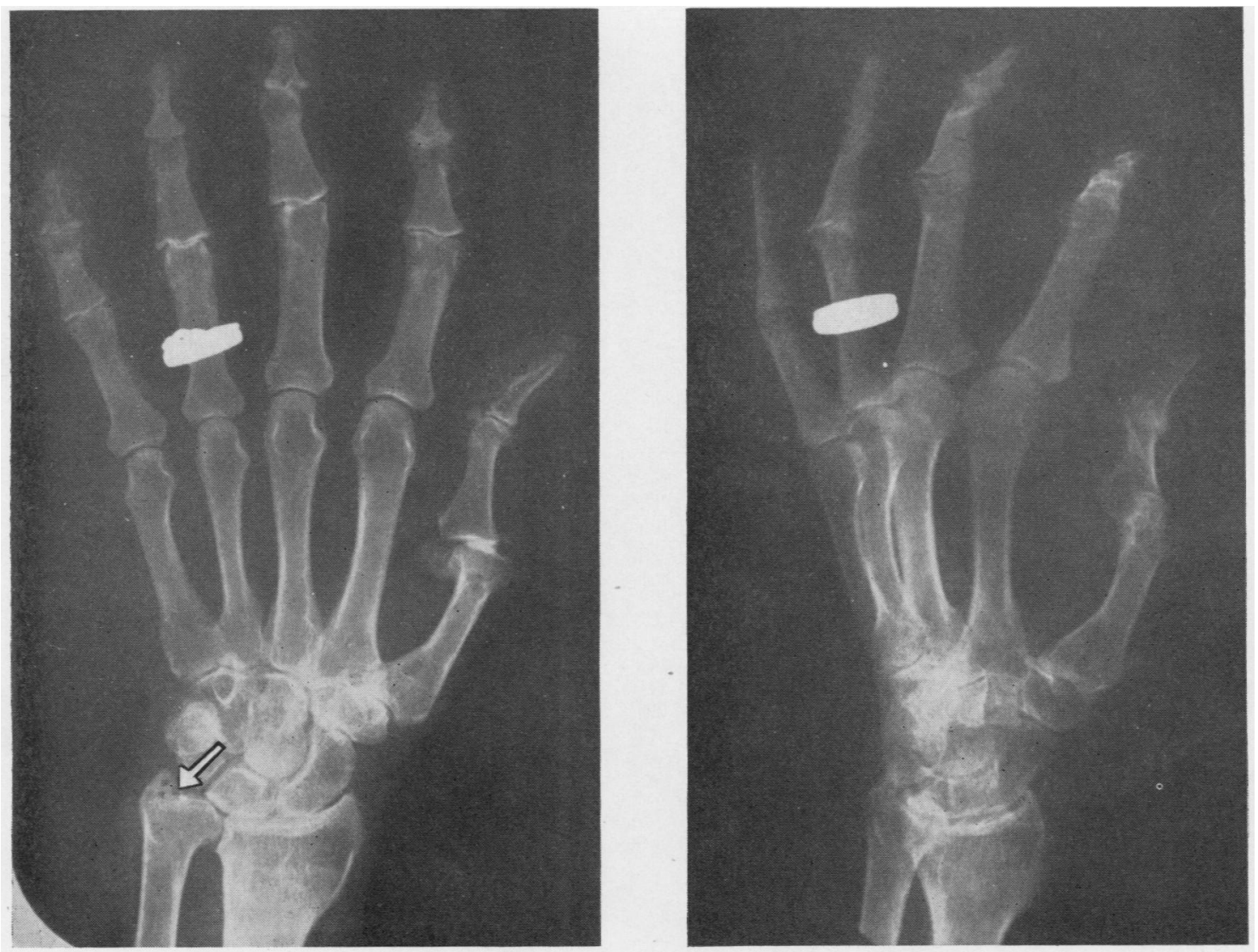


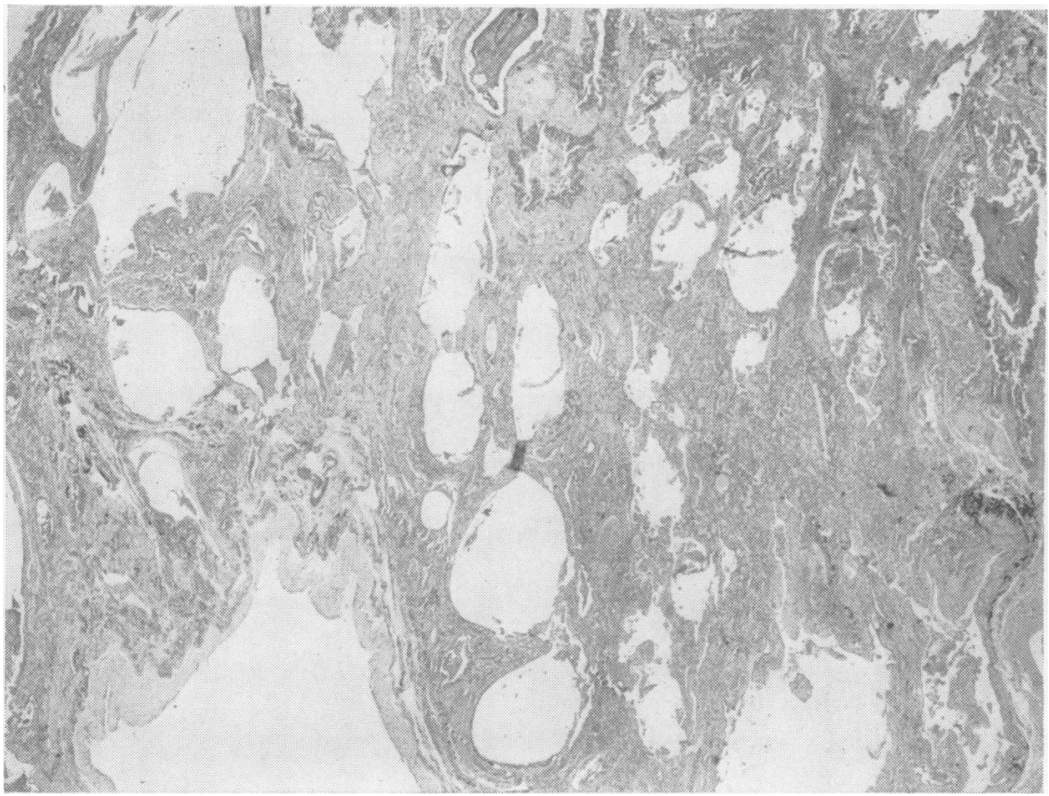

Fig. 6(a).--Low-power view of lung of Case 12, showing interstitial fibrosis obliterating some of the alveoli with breaking down of other alveoli to give a honeycomb appearance $(\times 9)$.

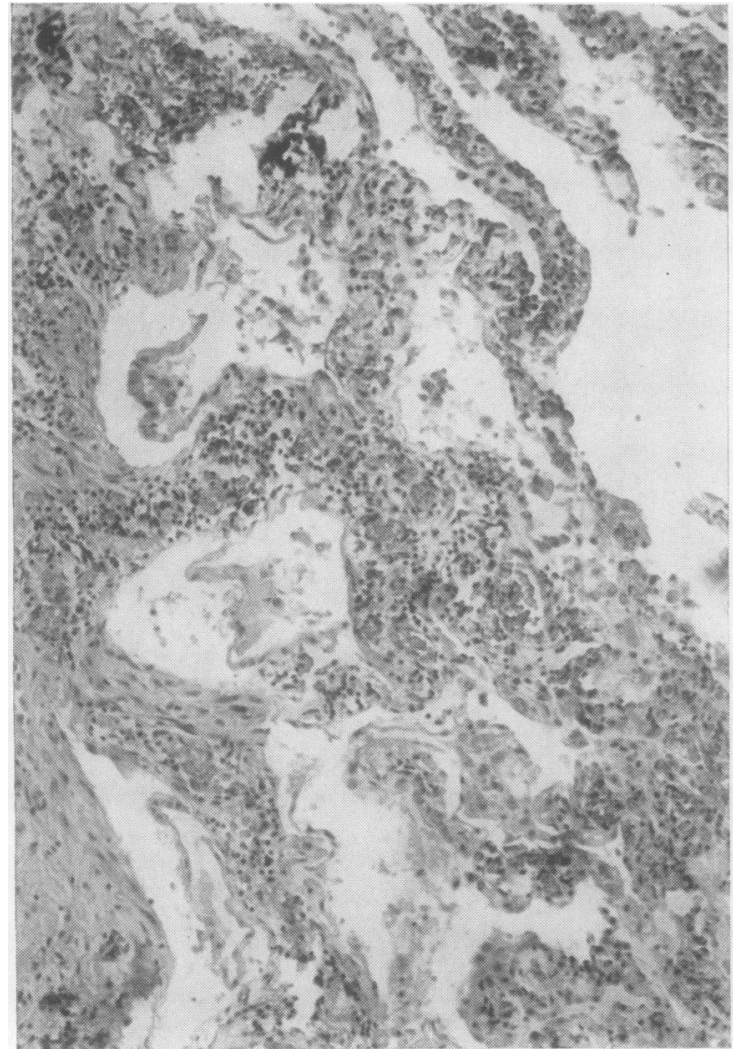

Fig. 6(b) - - Lung section of Case 12, showing fibroblasts and immature fibrous tissue causing interstitial thickening. Some of the alveoli are obliterated while the walls of other alveoli and bronchioles are broken down to form cystic spaces. Heavy infiltration by mononuclear cells $(\times 60)$.

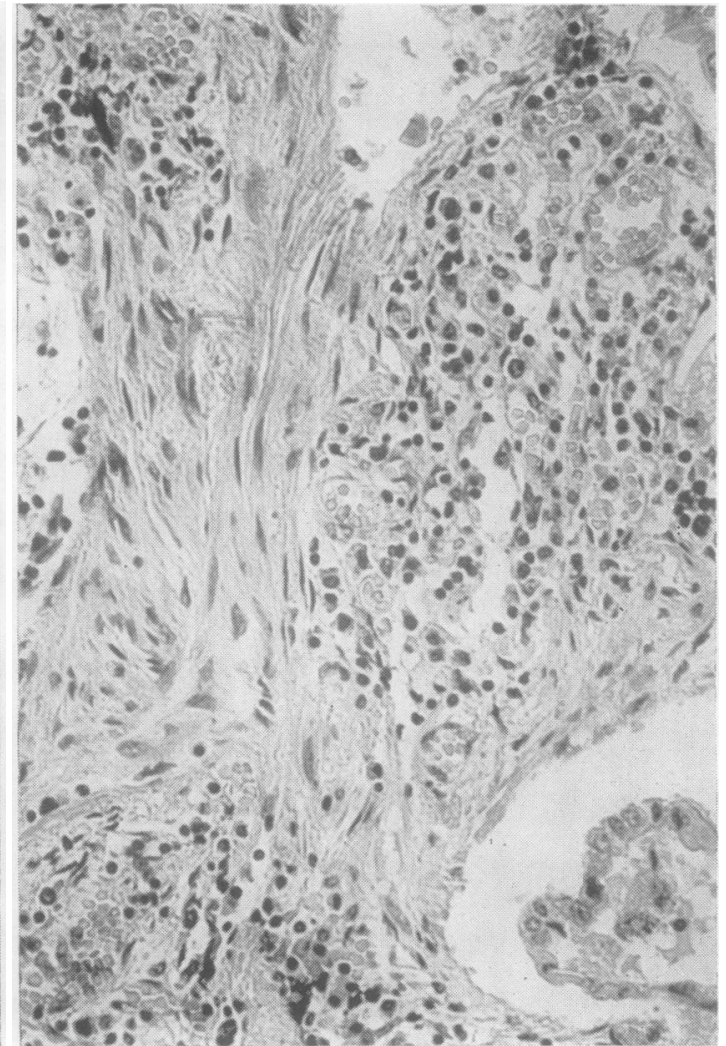

Fig. 6(c).-Different area in same lung, showing massive replacement by dense fibrous tissue $(\times 160)$. 
Summary of Clinical, Respiratory, Physiological, and Radiological Features

All the patients had some degree of dyspnoea and most gave a history of slowly progressive breathlessness, associated with a cough but very scant mucoid sputum. All had finger clubbing which, although in many considerable, was not associated with osteo-arthropathy. In most patients persistent râles were heard over both lungs. All were tuberculin positive. In no case was chest pain a feature.

Of the six cases in whom full function tests were done, four showed evidence of shunting or "alveolarcapillary block" with reduced carbon monoxide diffusion at rest and on exercise, but normal $\mathrm{PCO}_{2}$, $\mathrm{N}_{2}$ wash-out time and F.E.V./V.C. ratio. The other two patients had clinical evidence of co-existing obstructive airway disease and gave results compatible with a mixed pathology.

The chest $x$-ray findings resembled those described by previous authors (Livingstone and others, 1964). Briefly, they varied from basal reticular shadowing to a ground-glass appearance with stippling throughout the lung fields. Sometimes there was a combination of the two types of shadowing and in some cases cystic translucencies could be seen. Satisfactory bronchograms were available for two patients and these showed diminution of the peripheral clear zone.

Radiographs of the hands, feet, and cervical spine were available in fourteen of the nineteen cases. These were assessed by a radiologist who was unaware of the serological findings, in accordance with the criteria of the American Rheumatism Association as described by Bland, Davis, London, Van Buskirk, and Duarte (1963). No abnormality was seen in the joints of six patients; in three there were changes of osteo-arthritis only.

In five cases the presence of early rheumatoid changes could not definitely be excluded. Two of these have already been described: in Case 6 the S.C.A.T. was found positive on one occasion, and in Case 12 it was consistently negative before death. Of the remaining three cases, the S.C.A.T. was positive in two who showed radiologically some evidence of rheumatoid disease (Cases 2 and 11); in Case 2 there was one very small erosion in the head of the metacarpal bone of the left index finger (Fig. 7), Case 11 had some demineralization of the

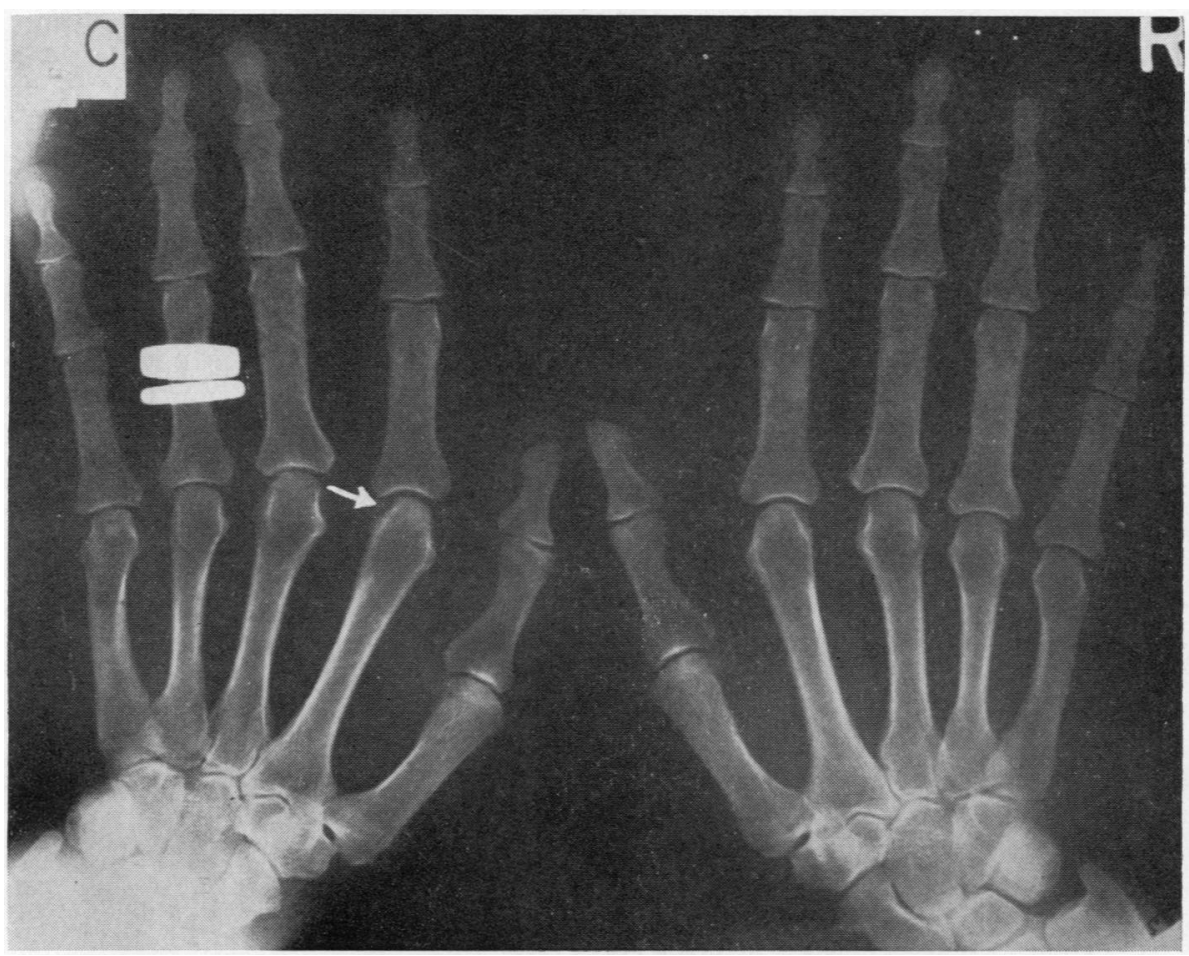

Fig. 7.-Case 2, showing very small erosion on ulnar side of head of metacarpal of left index finger. 
carpus with irregularity of the bone texture in the head of the metacarpal bone of the right index finger. The third (Case 14) had an erosion in the head of the first left metatarsal bone (Fig. 8), the S.C.A.T. being consistently negative.

\section{Outcome}

Of nineteen patients three only remain at work. Four have died in respiratory failure and the rest are disabled in varying degree, four of them being respiratory cripples. Histological proof of the diagnosis was obtained in three cases after death in hospital, and also in one other case in which a lung biopsy was done. Corticosteroid therapy was given a trial in five cases, including two of those who succumbed, but it did not appear to alter the course of the disease.

\section{Results of Serological Tests and Serum Globulin Levels}

The sheep cell agglutination and latex tests were carried out more than once in eighteen of our series of nineteen cases.

The S.C.A.T. remained consistently positive in four, and in another up to the time of his death. In a further five cases the test, originally positive, became negative. In one case the test, originally negative, was positive 3 months later but had become negative again when repeated after another 7 months. In seven cases the test was always negative.

When the S.C.A.T. was positive the latex test was almost always positive also, although when one test was strongly positive the other sometimes was only moderately so, as will be seen from the Table.

S.C.A.T. and latex tests were also carried out in an almost equal number of control cases, none of whom had evidence of rheumatoid arthritis. These were uniformly negative.

A serum globulin of over $3.6 \mathrm{~g} . / 100 \mathrm{ml}$. was found in fourteen patients; of these six had a consistently negative S.C.A.T. All cases with a positive S.C.A.T. also had a high serum globulin level, but in an individual case the highest S.C.A.T. titre was not invariably associated at the same time with the highest serum globulin level recorded.

\section{Discussion}

Ball (1955) appears to have been the first to use the sheep cell agglutination test in the investigation of patients with lung disease. In a survey of coalminers suffering from rheumatoid arthritis plus silicosis, he found that the presence of progressive massive fibrosis in the lungs was related to the
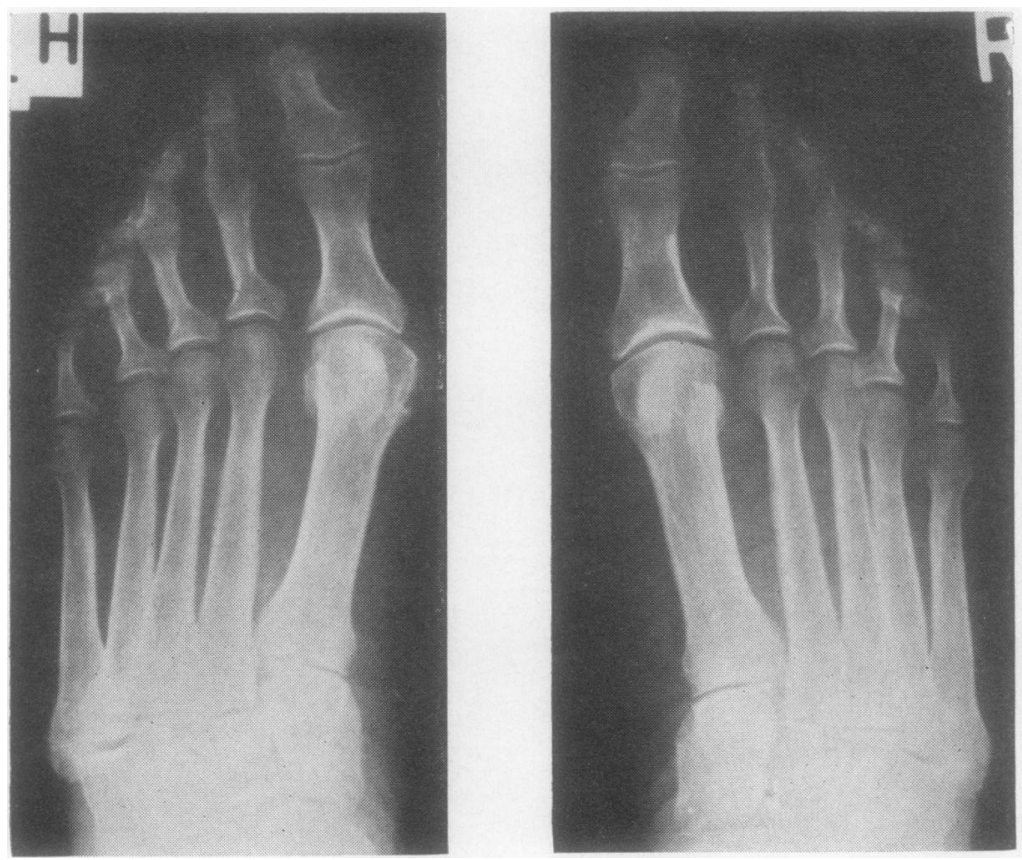

Fig. 8.-Case 14, showing erosion on medial side of head of metatarsal of left great toe. S.C.A.T. negative. 
incidence of positive serological tests. Kellgren and Ball (1959) forecast the value of this test in the investigation of certain cases of obscure lung disorder.

Having used the S.C.A.T. in cases of unexplained pleural effusion (Ward, 1961), we have lately carried it out in all patients presenting unusual pulmonary radiological features.

In our group of nineteen patients suffering from chronic interstitial pulmonary fibrosis, eleven had at some time a positive S.C.A.T. and latex-fixation test. The fact that the serological tests may revert to negative, or become positive after initial negative findings (Case 6) is in accord with clinical experience of patients with conventional rheumatoid disease. The latex-fixation tests closely paralleled the results of the S.C.A.T. as will be seen from the Table.

None of the nineteen patients suffered from clinical rheumatoid arthritis but we found minimal rheumatoid changes in five of those whose joints were $x$-rayed. Two of these (Cases 12 and 14) had negative S.C.A.T. and latex tests. There were therefore thirteen cases with some evidence of rheumatoid disease as judged by the presence, at some time, of the rheumatoid factor in the serum or radiological evidence of the disease.

Our results confirm the findings of various American authors; for example Franklin, ZuckerFranklin, and McEwen (1959), speaking at the Pan-American Congress of Rheumatic Diseases, discussed a small group of patients with diffuse pulmonary fibrosis in whom various tests for rheumatoid factor were positive; although some of their patients had clinical rheumatoid, in others the joints were normal. Ognibene (1960) described another case without rheumatoid disease, and Tomasi, Fudenberg, and Finby (1962) found positive serological tests for rheumatoid factor in 61 per cent. of eighteen patients with idiopathic pulmonary fibrosis. We consider that our findings are of added interest in view of the negative serological results in the two larger series of cases of idiopathic fibrosis published in this country by Scadding (1960) and Livingstone and others (1964).

In considering the aetiological significance of these findings, it is noteworthy that Ellman and Ball (1948) first drew attention to the protean pathological manifestations of "rheumatoid disease". Since then various pulmonary conditions associated with rheumatoid arthritis have been recognized although some years elapsed before it was generally accepted that pulmonary fibrosis and pleural effusion occurred as part of the clinical picture of rheumatoid disease. Caplan's syndrome (Shanks and Kerley, 1957-62) and rheumatoid pleural effusion (Horler and Thompson, 1959; Ward, 1961) may develop years before the joint lesions.

Lee and Brain (1962) described three cases of chronic interstitial pulmonary fibrosis in which rheumatoid disease developed later, and they concluded that these supported the hypothesis that "some examples of chronic interstitial pulmonary fibrosis are manifestations of rheumatoid disease".

Stretton and Leeming (1964) discussed the relationship of chronic interstitial pulmonary fibrosis to the connective tissue disorders and described two cases in which the S.C.A.T. was positive. One of their cases showed evidence of an old minor erosive arthropathy and both had raised serum globulin levels. They concluded that their findings were indicative of the presence of rheumatoid disease despite the absence of joint symptoms. They postulated three groups of chronic interstitial pulmonary fibrosis: those also showing clinical rheumatoid arthritis, those without clinical rheumatoid disease but with positive serology, and those considered as idiopathic.

Our cases, however, show considerable overlap between the second and third groups, the serology being found to change in some patients from positive to negative, and from negative to positive over a period of time. Also, when careful radiography of the hands, feet, and neck is done in "idiopathic" cases, unexpected evidence of minor rheumatoid changes may be revealed.

We consider that our findings of the presence of the rheumatoid factor in 58 per cent. of our group of cases of interstitial pulmonary fibrosis, with raised serum globulin in 65 per cent., are significant. In addition, we suggest that frequent repetition of these tests is important and that radiography of the hands, feet, and cervical spine should be done routinely. We believe that some if not most cases of chronic interstitial pulmonary fibrosis of otherwise unexplained origin belong to the group of collagen disorders, and that many are probably connected in some way with rheumatoid disease.

\section{Summary}

In nineteen cases of chronic interstitial pulmonary fibrosis, the sheep cell agglutination test has remained positive in five; one case originally negative became positive and later negative again. Five cases originally positive became negative and in seven cases the test was always negative. In one case the test was not done. The results of the latex-fixation test were very similar. The time sequence of the tests is shown in detail in a Table.

In fourteen of the cases the maximum serum globulin level recorded was greater than $3 \cdot 6 \mathrm{~g} . / 100 \mathrm{ml}$. 
None of the patients had overt rheumatoid disease, but in five of them $x$ rays of the hands and feet showed minimal rheumatoid changes; in two of these the serological tests were consistently negative.

We believe that some if not most cases of chronic interstitial pulmonary fibrosis belong to the group of collagen disorders, many being probably connected in some way with rheumatoid disease.

We wish to thank Dr. E. Beetles and Dr. Q. Moore of the Radiology Department, Blackburn Royal Infirmary, for the radiological reports, Dr. M. S. Spink for carrying out and advising on the S.C.A.T. in these and numerous other cases, Mr. P. Jewsbury for the lung biopsy on Case 16, and Dr. C. K. Heffernan for pathological and histological reports. We should especially like to thank Dr. S. S. Chatterjee of the Department of Respiratory Physiology, Baguley Hospital, Manchester, who carried out the lung function tests.

\section{REFERENCES}

Ball, J. (1955). Ann. rheum. Dis., 14, 159.

Bland, J. H., Davis, P. H., London, M. G., Van Buskirk, F. W., and Duarte, C. G. (1963). Arch. intern. Med., 112, 892.

Ellman, P., and Ball, R. E. (1948). Brit. med.J., $2,816$.

Finley, T. N., Swenson, E. W., and Comroe, J. H., Jr. (1962). J. clin. Invest., 41, 618.

Franklin, E. C., Zucker-Franklin, D., and McEwen, C. (1959). A.I.R. Arch. interamer. Rheum. (Rio de J.), $2,250$.

Horler, A. R., and Thompson, M. (1959). Ann. intern. Med., 51, 1179.

Kellgren, J. H., and Ball, J. (1959). Brit. med. J., 1, 523.

Lancet (1964). 1, 1202.

Lee, F. I., and Brain, A. T. (1962). Lancet, 2, 693.

Livingstone, J. L., Lewis, J. G., Reid, L., and Jefferson, K. E. (1964). Quart. J. Med., 33, 71 .

Ognibene, A. J. (1960). Arch. intern. Med., 105, 762.

Scadding, J. G. (1960). Brit. med. J., 1, 443.

Shanks, S. C., and Kerley, P. (1957-62). "A Text-Book of $X$ ray Diagnosis", 3rd ed. Lewes, London.

Stretton, T. B., and Leeming, J. T. (1964). Thorax, $19,79$.

Tomasi, T. B., Fudenberg, H. H., and Finby, N. (1962). Amer. J. Med., 33, 243.

Ward, R. (1961). Lancet, 2, 1336.

West, J. B. (1964). Ibid, 1, 1274.
La réaction de Waaler-Rose dans la fibrose pulmonaire interstitielle chronique

RÉSUMÉ

Dans 5 cas sur 19 de fibrose pulmonaire interstitielle chronique la réaction de Waaler-Rose demeura positive; dans un cas elle fut négative pour commencer, positive ensuite et négative une fois de plus. Cinq cas positifs au début devinrent négatifs et dans 7 cas cette réaction fut toujours négative. Dans un cas on ne procéda pas à la réaction. Les résultats de la réaction de fixation au latex furent très similaires. L'ordre successif des réactions est indiqué en détail dans la Table ci-dessus.

Dans 14 cas on enrégistra un taux sérique maximum de globuline au dessus de $3.6 \mathrm{~g} . / 100 \mathrm{ml}$.

Aucun malade ne présenta de maladie rhumatoïde franche, mais cinq radiographies des mains et des pieds accusèrent des altérations rhumatoïdes minimes; chez deux d'entre eux les réactions sérologiques furent constamment négatives.

Nous croyons que certains cas de fibrose pulmonaire interstitielle chronique, sinon leur majeure partie, appartiennent au groupe des désordres du collagène, beaucoup d'entre eux étant probablement liés de façon ou d'autre à la maladie rhumatoïde.

\section{La reacción de Waaler-Rose en la fibrosis pulmonar intersticial crónica}

\section{SUMARIO}

De 19 casos de fibrosis pulmonar intersticial crónica, la reacción de Waaler-Rose quedó positiva en cinco; en un caso fué negativa para empezar, luego positiva y finalmente volvió a ser negativa. Cinco casos positivos se volvieron negativos y en siete casos esta reacción fué siempre negativa. En un caso ne se hizo la reacción. Los resultados de la reacción de fijación en latex fueron muy parecidos. El orden sucesivo de las reacciones se ve indicado detallademente en el Cuadro.

En 14 casos las mayores cifras de globulina sérica fueron más de $3.6 \mathrm{~g} . / 100 \mathrm{ml}$.

Ninguno de los enfermos presentó una enfermedad reumatoide franca, pero cinco radiografías de manos y de pies acusaron alteraciones reumatoides ligeras; en uno de estos enfermos las reacciones serológicas fueron siempre negativas.

Creemos que ciertos casos de fibrosis pulmonar intersticial crónica, o quizás la mayoría de ellos, pertenecen al grupo de disturbios del colágeno, siendo muchos de ellos ligados probablemente de una manera o de otra a la enfermedad reumatoide. 